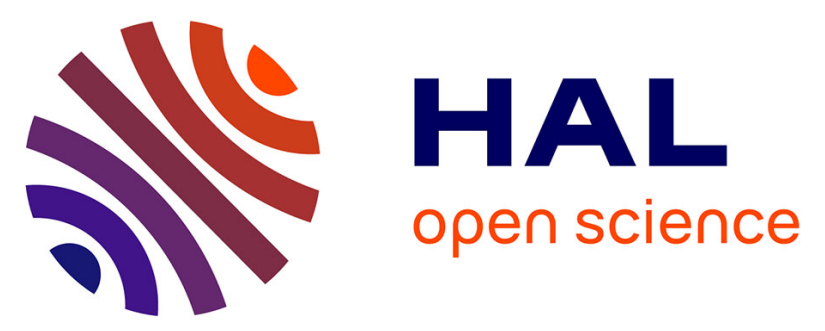

\title{
Irrigation return flows in a mediterranean aquifer inferred from combined chloride and stable isotopes mass balances
}

\author{
Christine Vallet-Coulomb, Pierre Séraphin, Julio Gonçalvès, Olivier
} Radakovitch, Anne-Laure Cognard-Plancq, Agnès Crespy, Milanka Babic, François Charron

\section{To cite this version:}

Christine Vallet-Coulomb, Pierre Séraphin, Julio Gonçalvès, Olivier Radakovitch, Anne-Laure Cognard-Plancq, et al.. Irrigation return flows in a mediterranean aquifer inferred from combined chloride and stable isotopes mass balances. Applied Geochemistry, 2017, 86, pp.92 - 104. 10.1016/j.apgeochem.2017.10.001 . hal-01635330

\section{HAL Id: hal-01635330 https://hal.science/hal-01635330}

Submitted on 20 Feb 2022

HAL is a multi-disciplinary open access archive for the deposit and dissemination of scientific research documents, whether they are published or not. The documents may come from teaching and research institutions in France or abroad, or from public or private research centers.
L'archive ouverte pluridisciplinaire HAL, est destinée au dépôt et à la diffusion de documents scientifiques de niveau recherche, publiés ou non, émanant des établissements d'enseignement et de recherche français ou étrangers, des laboratoires publics ou privés. 


\title{
Irrigation return flows in a mediterranean aquifer inferred from combined chloride and stable isotopes mass balances
}

\author{
Christine Vallet-Coulomb ${ }^{\mathrm{a}, *}$, Pierre Séraphin ${ }^{\mathrm{a}}$, Julio Gonçalvès ${ }^{\mathrm{a}}$, Olivier Radakovitch ${ }^{\mathrm{a}}$, \\ Anne-Laure Cognard-Plancq ${ }^{\mathrm{b}}$, Agnès Crespy ${ }^{\mathrm{a}}$, Milanka Babic ${ }^{\mathrm{b}}$, François Charron ${ }^{\mathrm{c}}$ \\ a Aix Marseille Université, CNRS, IRD, CEREGE UM 34, 13545 Aix en Provence, France \\ ${ }^{\mathrm{b}}$ Avignon Université, INRA, EMMAH UMR 1114, 84000, Avignon, France \\ ${ }^{\mathrm{c}}$ Montpellier SupAgro, Domaine du Merle, UMR G-Eau, Route d'Arles, 13300 Salon de Provence, France
}

\section{A R T I CLE INFO}

Editorial handling by: Elisa Sacchi.

\section{Keywords:}

Groundwater recharge

Irrigation return flow

Stable isotopes

Chloride mass balance

\begin{abstract}
A B S T R A C T
The supply of irrigation water often overcomes crop evapotranspiration, and the resulting return flow may infiltrate and significantly contribute to an aquifer water budget. Despite its crucial importance for water resource management, the proportion of irrigation water that contributes to groundwater recharge, namely the return flow coefficient, often remains difficult to assess. Here, a chloride mass balance is combined with an isotopic mixing model $\left(\delta^{18} \mathrm{O}\right.$ and $\left.\delta \mathrm{D}\right)$ to quantify return flow coefficients, in the Crau alluvial-type aquifer (Southern France), characterized by a long-term traditional practice of flood irrigation. Local groundwater compositions are interpreted in terms of average recharge along different flow paths. The high isotopic contrast between irrigation water and regional precipitation allows the partitioning of recharge between rainfall infiltration and irrigation return flows. Isotopic mixing proportions are then used to decipher the chloride concentration of groundwater purely recharged by return flow. This allows an original application of the chloride mass balance approach to estimate return flow coefficients, which doesn't rely on any atmospheric chloride survey. Values around $0.53 \pm 0.16$ were found for well defined stream lines averaging the functioning of the upstream aquifer, which leads to a return flow rate of $1190 \pm 140 \mathrm{~mm} \mathrm{yr}^{-1}$. These results are consistent with a local daily time series of recharge fluxes derived from the water-table fluctuation method over the 2003-2009 period, and in line with the spatial average previously quantified over the whole aquifer. This study confirms the ability of geochemical tracers to provide recharge rates fully independent from flux measurements. They can be further used to assess the irrigation efficiency in other similar systems, or to monitor the variations of irrigation return flow, which will result from the future modifications of land use, irrigation practices and climate.
\end{abstract}

\section{Introduction}

A smart and sustainable management of groundwater resource requires a comprehensive estimate of all human influences. Besides the direct impact of groundwater abstraction, land use and agricultural practices indirectly influence aquifer water budgets through a modification of recharge fluxes, especially when irrigation water is provided in excess to evapotranspiration (Scanlon et al., 2007; Meixner et al., 2016). The contribution of irrigation return flow to groundwater recharge may represent a major component of an aquifer water budget (Jiménez-Martinez et al., 2010), particularly in the case of flood irrigation, which is the most water consuming practice (Kendy et al., 2004;
Liu et al., 2005; Tang et al., 2007). Improving irrigation efficiency through the reduction of the return flow is often desired for reducing water consumption, and preventing groundwater salinization mechanisms (Bresciani et al., 2014; Dewandel et al., 2008; Stigter et al., 1998; Yakirevich et al., 2013). Nevertheless, the contribution of return flows may constitute a substantial and sustainable support to local water resource, especially when irrigation supply comes from remote and well watered catchments (Kendy et al., 2004; Scanlon et al., 2007; Cruz-Fuentes et al., 2014; Tang et al., 2007).

The Crau aquifer (Southern France) is an illustration of the complex interactions and feedbacks between land-use, irrigation practices, climate and recharge. Supplying large areas of meadows, flood irrigation

\footnotetext{
* Corresponding author.

Email address: valletcoulomb@free.fr (C. Vallet-Coulomb)
} 
is performed following traditional practices for high quality hay production. Despite a typical Mediterranean climate with frequent drought, strong winds and high evapotranspirative demand, this water-intensive practice was made possible for hundreds of years by the abundance of water coming from the neighbouring alpine mountains, through the Durance River. Because of the high permeability of the aquifer, water rapidly infiltrates and irrigation return flow currently constitutes the main source of aquifer recharge (Albinet et al., 1969; Courault et al., 2010; Mailhol and Merot, 2008; Olioso et al., 2013; Séraphin et al., 2016). The local groundwater resource, which is intensively exploited for water consumption (drinking water, industry and other agricultural production), is thus mainly supplied by an external watershed, the Durance River Basin, through irrigation return flows. Nevertheless, this fragile equilibrium is threatened by different factors. Among them, the increasing urbanisation in the Crau Plain leads to reduce the areas devoted to flood irrigation. In addition, more frequent droughts are expected in the near future, and the increasing pressure on the water resource provided by the Durance River encourages a reduction of irrigation water consumption, and thus, a reduction of return flows. The improvement of irrigation efficiency or the reduction of irrigated surfaces would have a negative impact on the water budget of the Crau aquifer. A comprehensive evaluation of irrigation efficiency and return flows is thus necessary to manage human activities and optimize water resource use.

As an alternative to groundwater modelling tools, geochemical tracers can be used to determine sources of recharge, mixing processes, and in some cases, recharge rates independent of any hydrogeological data (Harrington et al., 2002; Scanlon et al., 2002). Stable isotopes of the water molecule $\left({ }^{18} \mathrm{O}\right.$ and $\left.\mathrm{D}\right)$ can provide the relative contributions of different sources of groundwater, when contrasted isotopic signatures are involved, for example when recharge comes from high elevation regions (Blasch and Bryson, 2007; Guglielmi et al., 1998; Liu and Yamanaka, 2012; Wahi et al., 2008), or from vertical leakage of deep aquifers with distinct isotopic signatures (Gonçalvès et al., 2015). The seasonality of precipitation composition may also help to decipher the relative contributions of different seasonal recharges (Jasechko et al., 2014; Winograd et al., 1998). Stable isotopes are particularly well suited for the tracing of irrigation return flow, as far as the signature of irrigation water is different from that of the local groundwater background (Duque et al., 2011; Séraphin et al., 2016). Nevertheless, isotope partitioning only provides flux proportions, and the quantification of recharge rates still requires a flux estimate.

A chloride mass balance approach can be used to estimate recharge rates. Initially proposed by Eriksson and Khunakasem (1969), a number of successful applications of the method have been reported (e.g. Alcala and Custudio, 2014; Dassi, 2011; Edmunds et al., 2002; Edmunds and Gaye, 1994; Gates et al., 2008; Naranjo et al., 2015). It relies on a full understanding of the origin of the chloride, and on the assumption that evapotranspiration does not export chloride. Its applicability for estimating recharge rates due to rainfall infiltration requires a robust quantification of atmospheric chloride inputs, which may limit the conditions for a robust application, particularly in coastal areas characterized by strong spatial variations. Alternatively, we propose to use the chloride mass balance to estimate irrigation return flow coefficients, defined as the proportion of irrigation water that contributes to groundwater recharge, which becomes possible if the chloride concentration of groundwater purely recharged by return flow can be isolated from that of natural recharge, using a conservative tracer of mixing proportions.

The proposed methodology focuses on the interpretation of individual groundwater sampling locations, representative of their upstream flowpath, accounting for their respective land cover. Based on a one-year survey of $\delta^{18} \mathrm{O}, \delta \mathrm{D}$ and chloride concentration in irrigation water and seven groundwater sampling locations, the chloride mass balance approach is combined with a stable isotope mixing model to propose a quantification of irrigation return flows coefficients, which is i) fully independent of groundwater flux estimates and ii) able to evaluate recharge fluxes at a more detailed scale. Results are compared with recharge rates obtained locally and independently from the analysis of water table fluctuation (WTF) over a seven-year period.

\section{Site description}

\subsection{Environmental and hydrogeological setting}

Located in Southern France, under a Mediterranean climate, the Crau plain $\left(540 \mathrm{~km}^{2}\right)$ houses a shallow unconfined aquifer, which represents one of the most important regional groundwater resources. Limited to the north by the Alpilles Range, to the east by the Miramas Hills and to the west by the Rhône River delta (Fig. 1), the plain is formed by an extensive stretch of coarse alluvial deposits accumulated during the Plio-Quaternary period, and carried from the Alps by the Durance River. The alluvial material, which is more or less cemented, forms a highly permeable aquifer (average permeability of $210^{-3} \mathrm{~m} \mathrm{~s}^{-1}$ ). The course of the Durance River has abandoned the Crau plain and moved to the north of the Alpilles Range, towards the Rhône River sometime between 75 and 35 ka (Molliex et al., 2013), and no natural drainage network remains nowadays. The absence of a river network comes from the very flat relief, combined with the high infiltration capacity of soil surfaces. Except along the downstream limit of the aquifer, the water table remains too deep for allowing access to groundwater for evapotranspiration (average unsaturated zone thickness of $6 \mathrm{~m}$ ), and the natural surfaces are covered by a characteristic dry grassland plant community, forming a natural reserve with a steppic ecosystem locally called "Coussoul", where traditional itinerant sheep grazing is practiced (Buisson and Dutoit., 2006; Masson et al., 2015). Besides natural surfaces, a large proportion of the Crau plain is covered by irrigated meadows $\left(140 \mathrm{~km}^{2}\right.$ in 2009). These meadows are characterised by well-developed soils resulting from the long-term accumulation of rich silty sediments carried by irrigation water during almost 500 years of traditional flood irrigation practices (Courault et al., 2010).

In the North-eastern part of the Crau plain, the Merle Experimental Domain is a $4 \mathrm{~km}^{2}$ area, representative of the main land use types characterising the Crau Plain, with $1.5 \mathrm{~km}^{2}$ of irrigated meadows and $2.5 \mathrm{~km}^{2}$ of natural surfaces. In addition, the upstream part of the aquifer area corresponds to the most important density of irrigated meadows. The Merle Domain is managed with a threefold objective: agricultural production (hay production, and traditional sheep grazing), training centre for shepherds and farmers, and experimental setting for research projects.

\subsection{Irrigation practices}

Since the 16th Century, the Crau plain is covered by a dense network of irrigation canals that takes water from the Durance River at about $20 \mathrm{~km}$ North-East of Salon-de-Provence (Fig. 1). Flood irrigation is performed for high quality hay production under an official national label ("A.O.P. Foin de Crau"), which controls and maintains traditional agricultural practices. The irrigation season begins between March $15^{\text {th }}$-20th, with a progressively increasing rate of inflows. During the May-August period the irrigation inflows reach their maximum rates. The irrigation period also ends gradually: it continues at a lower rate from September until the middle of October, depending on the timing of the first autumn rainfalls. In case of high rainfall during the irrigation period $\left(\mathrm{P}>30 \mathrm{~mm}^{\text {day }}{ }^{-1}\right)$, irrigation can be delayed by an average of seven days corresponding to the time lag between two irrigation 


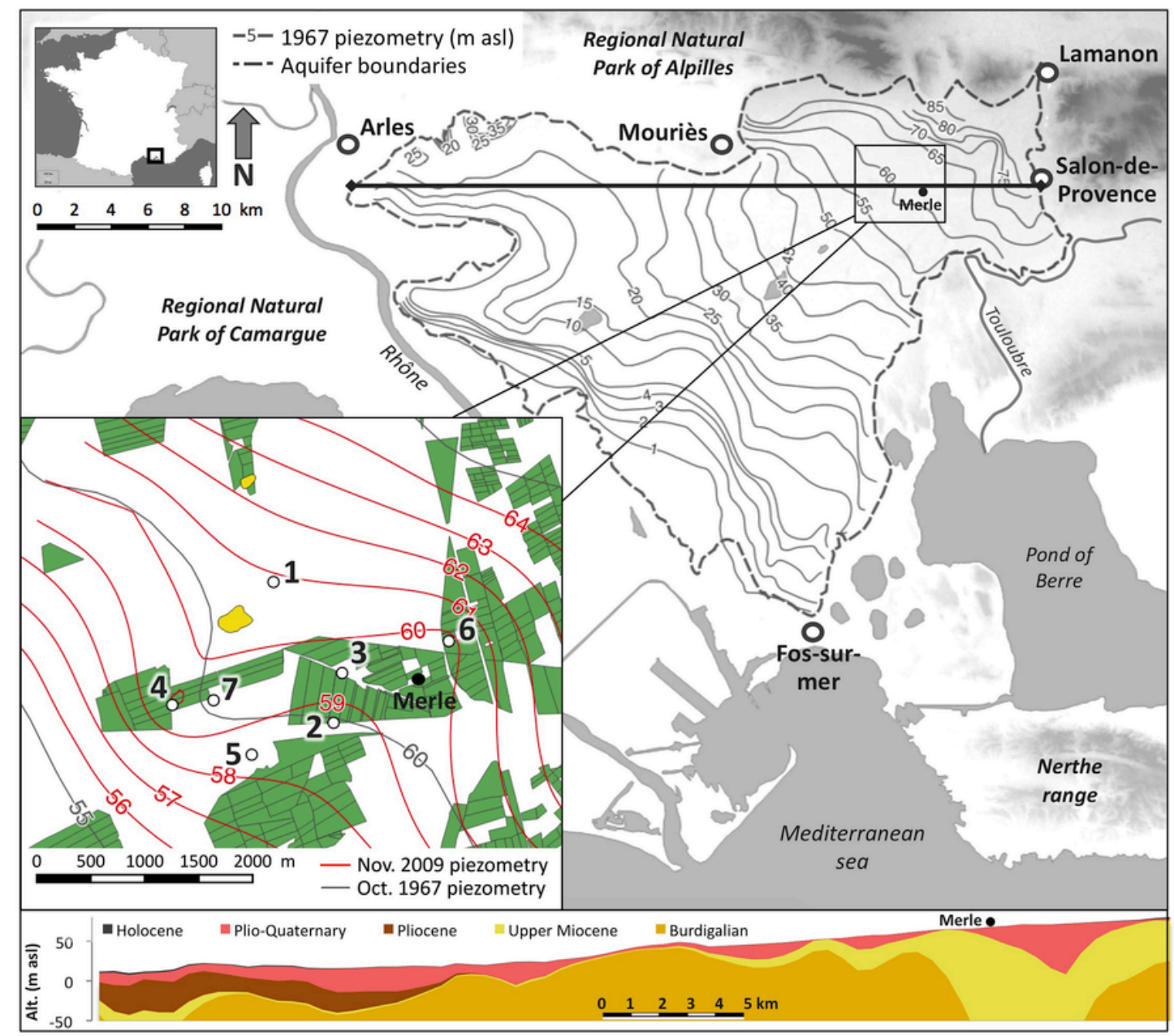

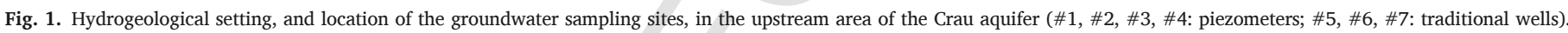

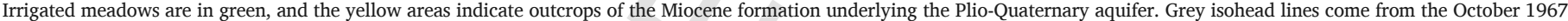

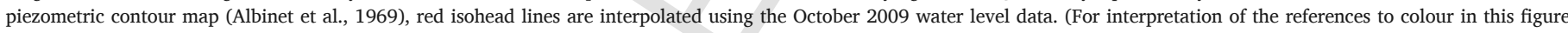
legend, the reader is referred to the web version of this article.)

turns on the same field. A total of $2000-2500 \mathrm{~mm} \mathrm{yr}^{-1}$ of irrigation water is brought to the meadows, which corresponds to a total of $280-350 \mathrm{hm}^{3} \mathrm{yr}^{-1}$ (data from the regional management agency).

\section{Hydraulic and geochemical data}

\subsection{Data acquisition}

A near-monthly sampling was carried out between October 2008 and November 2009 at three wells and four piezometers distributed in the Merle domain (Fig. 1), at locations representative of the characteristic environments encountered in the Crau plain: natural surfaces (\#1), irrigated meadows (\#2, \#3, \#4, \#6) and intermediate areas (\#5, \#7). Groundwater was pumped with a low flow rate $\left(\sim 6 \mathrm{~L} \mathrm{~min}^{-1}\right) \mathrm{im}-$ mersion pump and sampled when a stable electric conductivity was reached. Samples were also taken from the irrigation canal that supplies irrigation water during the whole irrigation season. The water table depth was measured manually during each sampling, and combined with soil elevation measured by a Differential Global Positioning System to obtain precise water elevation data. In addition, the groundwater level was measured at a daily time step in piezometer \#2 between January 2003 and November 2009, using an automatic pressure sensor $\left(10^{-3} \mathrm{~m}\right.$ of resolution). Daily precipitation, provided by "INRA Climatik Platform", was measured at the meteorological station located
$50 \mathrm{~m}$ from well \#7. The rainfall isotopic composition was obtained from the neighbouring GNIP station (Global Network for Isotopes in Precipitation), located at Avignon, $35 \mathrm{~km}$ North-Northwest from the Crau plain (IAEA/WMO, 2016), and supported by the Hydrogeochemical Laboratory of Avignon (LHA, rainfall sampling and corresponding isotopic measurements).

Water samples were analysed for their isotopic compositions $\left(\delta^{18} \mathrm{O}\right.$ and $\delta \mathrm{D}$ ) in the CEREGE laboratory. The samples were equilibrated with $\mathrm{CO}_{2}(10 \mathrm{~h}$ at $291 \mathrm{~K})$ and $\mathrm{H}_{2}(2 \mathrm{~h}$ at $291 \mathrm{~K}$ with a platinum catalyst $)$ for $\delta^{18} \mathrm{O}$ and $\delta \mathrm{D}$, respectively - in an automated HDO Thermo-Finnigan equilibrating unit and measured on a dual inlet Delta Plus mass spectrometer. All the analyses were replicated. Oxygen and hydrogen isotope ratios are reported in \%o relative to the SMOW-SLAP scale, following the IAEA reference sheet (IAEA, 2009) using three working standards previously normalized using VSMOW2, SLAP2 and GISP international standards. The total uncertainties for the $\delta^{18} \mathrm{O}$ and $\delta \mathrm{D}$ values were close to $0.05 \%$ o $(1 \sigma)$ and $1 \%$ o $(1 \sigma)$ respectively. A total of 77 groundwater samples and 10 canal water samples were analysed for $\delta^{18} \mathrm{O}$ and $\delta \mathrm{D}$. Chloride concentrations were measured in LHA by ion chromatography (Thermo Scientific ${ }^{\mathrm{TM}}$ Dionex $^{\mathrm{TM}}$ ion chromatography (IC) system). A total of 85 groundwater samples and 9 canal water samples were analysed for $\left[\mathrm{Cl}^{-}\right]$. 


\subsection{Water table variations}

Important seasonal variations in the water table occurred during the study period, with the highest levels reached during September, at the end of the irrigation season (Fig. 2). This clearly indicates the influence of irrigation return flows on the water table dynamics. The amplitudes of seasonal variations ranged between 1.4 and $8.4 \mathrm{~m}$. The lowest value corresponds to piezometer $\# 1$, located in a natural area, while higher amplitudes were found for observation points \#2, \#3, and \#6, which are all close to irrigated surfaces (Fig. 1).

Piezometer \#4 recorded a seasonal amplitude of only $3.0 \mathrm{~m}$, despite its location on the border of an irrigated meadow. This piezometer is located in an area where the aquifer is very thin $(6.0 \mathrm{~m}$ thick) and saturated almost up to the soil surface during the irrigation period (up to $0.9 \mathrm{~m}$ below the soil surface). In addition, the groundwater level rises earlier here (minimum level observed on 2009 March 9th), indicating an immediate response to irrigation return flows. The same holds for \#7, the closest well, which follows a similar seasonal behaviour than \#4 (Fig. 2). In addition, the water table level measured in piezometer \#4 remains higher than that obtained from all the other sampling locations during the irrigation season (Fig. 2). This leads to an irrigation mound on the piezometric map (Fig. 1), and indicates the particular importance of return flows at this location. Note that the piezometric map based on data from October 1967 (Albinet et al., 1969) already showed relatively high levels in this area, but the data were only based on traditional wells (\#5, \#6, \#7), since the piezometers used in the present study had not yet been drilled.

The daily record obtained from piezometer \#2 provides a long-term perspective and indicates that during the $2003-2009$ period, the magnitude of seasonal variations varied between $6.2 \mathrm{~m}$ (in 2004) and $8.1 \mathrm{~m}$ (in 2007). During the recording period, the annual maxima reached in September (59.5 $\mathrm{m}$ a.s.1.) remained relatively more stable $( \pm 0.6 \mathrm{~m})$ than the annual minima observed in spring $(52.4 \pm 1.0 \mathrm{~m}$ a.s.1.), which is more influenced by interannual variations in precipitation. The lowest water level observed in spring 2007 corresponds to the driest year of the period ( $301 \mathrm{~mm} \mathrm{yr}^{-1}$ ). Overall, the seasonal pattern, which qualitatively reflects the influence of irrigation return flows, is well repro- duced from year to year, with no apparent interannual trend. Regarding the short average groundwater residence time (1-2 years, deduced from the water balance of the whole aquifer, and using a specific yield of 0.1 , Albinet et al., 1969), this indicates an interannual behaviour close to the steady state.

\subsection{Geochemical compositions}

Groundwater isotopic compositions ranged between $\delta^{18} \mathrm{O}=-11.25 \%$ and $-8.67 \%$ ( $\delta \mathrm{D}=-82.0 \%$ and $-60.3 \% \circ$ ) for the sampling locations \#2 to \#7, while \#1 displayed a distinct enriched composition, ranging between $\delta^{18} \mathrm{O}=-6.9 \%$ and $-5.52 \%$ ( $\delta \mathrm{D}=-44.4 \% \circ$ and $-37.1 \%$ ) (Fig. 3-A and 4-A). For each sampling location, the isotopic composition remained generally stable throughout the annual cycle, especially \#2, which had the lowest standard deviation (Table 1). The most depleted values were encountered in \#4 and \#7, two sampling points located close to the irrigation mound observed in the piezometric map. Based on average values (Fig. 4-B, Table 1), groundwater sampled in piezometer \#1 was clearly more enriched than the other sampling locations: $\delta^{18} \mathrm{O}=-5.96 \% \circ(\delta \mathrm{D}=-40.5 \%$ ), and very close to the weighted average composition of regional precipitation: $\delta^{18} \mathrm{O}=-6.21 \pm 2.20 \%$ o and $\delta \mathrm{D}=-40.1 \% \circ \pm 16.8 \%$ or the Avignon GNIP station over the 1997-2009 period (average precipitation: $651 \mathrm{~mm} \mathrm{yr}^{-1}$ ).

The isotopic composition of irrigation water was distinctly more negative than the long-term average of local precipitation (Fig. 4-B), with an average composition of $\delta^{18} \mathrm{O}=-10.74 \% \circ \pm 0.63 \%$ and $\delta \mathrm{D}=-77.6 \%$ $\pm 5.1 \%$. This depleted isotopic composition, characteristic of alpine rivers, is explained by the orographic effect that controls precipitation formation in the Alps. It also corresponds to the average value of $\delta^{18} \mathrm{O}=-10.5 \%$ estimated by (Guglielmi et al., 1998) for regional alpine rivers. In the $\delta^{18} \mathrm{O}-\delta \mathrm{D}$ plot, the composition of irrigation water falls slightly below the Local Meteoric Water Line (Fig. 4), which reflects the influence of evaporation during the transport of water from the Alps. The maximum value was observed in irrigation water collected in April $\left(\delta^{18} \mathrm{O}=-9.67 \%\right.$; $\delta \mathrm{D}=-68.2 \%$ ) and the minimum in August $\left(\delta^{18} \mathrm{O}=-12,06 \%\right.$; $\delta \mathrm{D}=-87.8 \%$, Fig. $\left.3-\mathrm{A}\right)$. The low value in August is due to the retention of Alpine water in the main dam of the

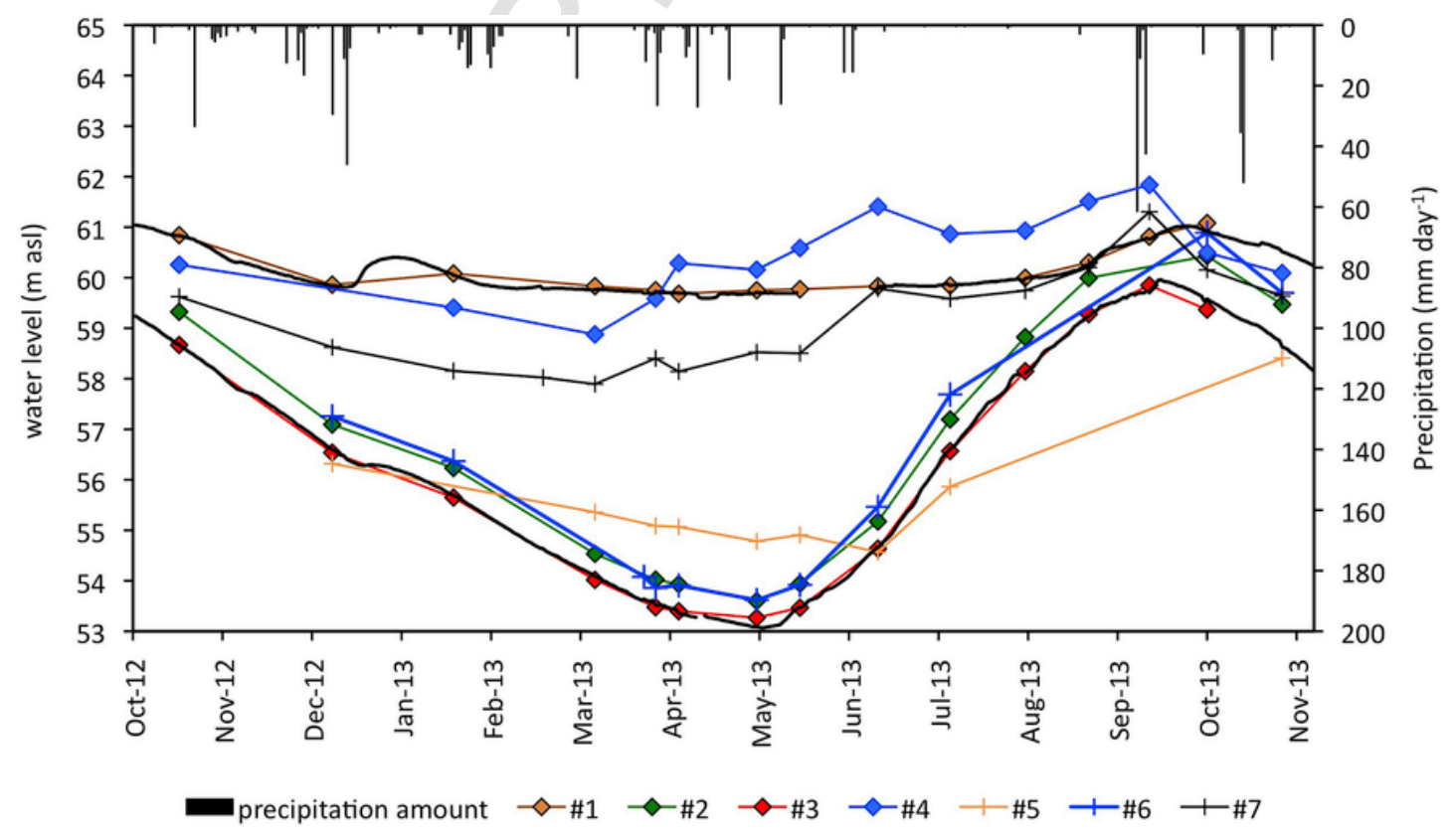

Fig. 2. Groundwater level measured manually during the study period. The daily automatic records available for \#1 and \#2 are also shown (continuous lines). 

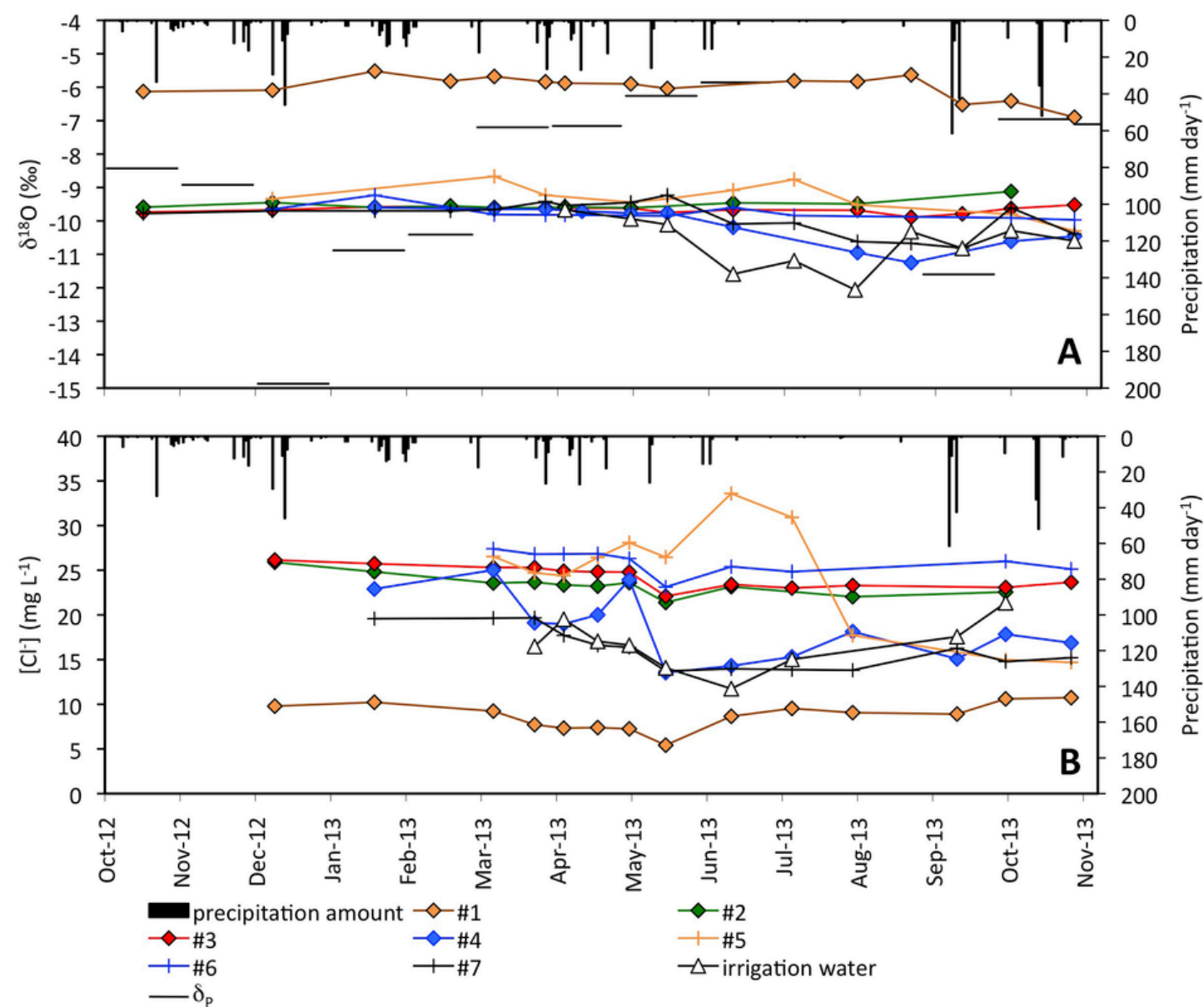

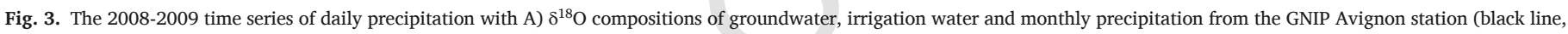
IAEA/WMO, 2016), and B) $\left[\mathrm{Cl}^{-}\right]$concentrations of groundwater and irrigation water.

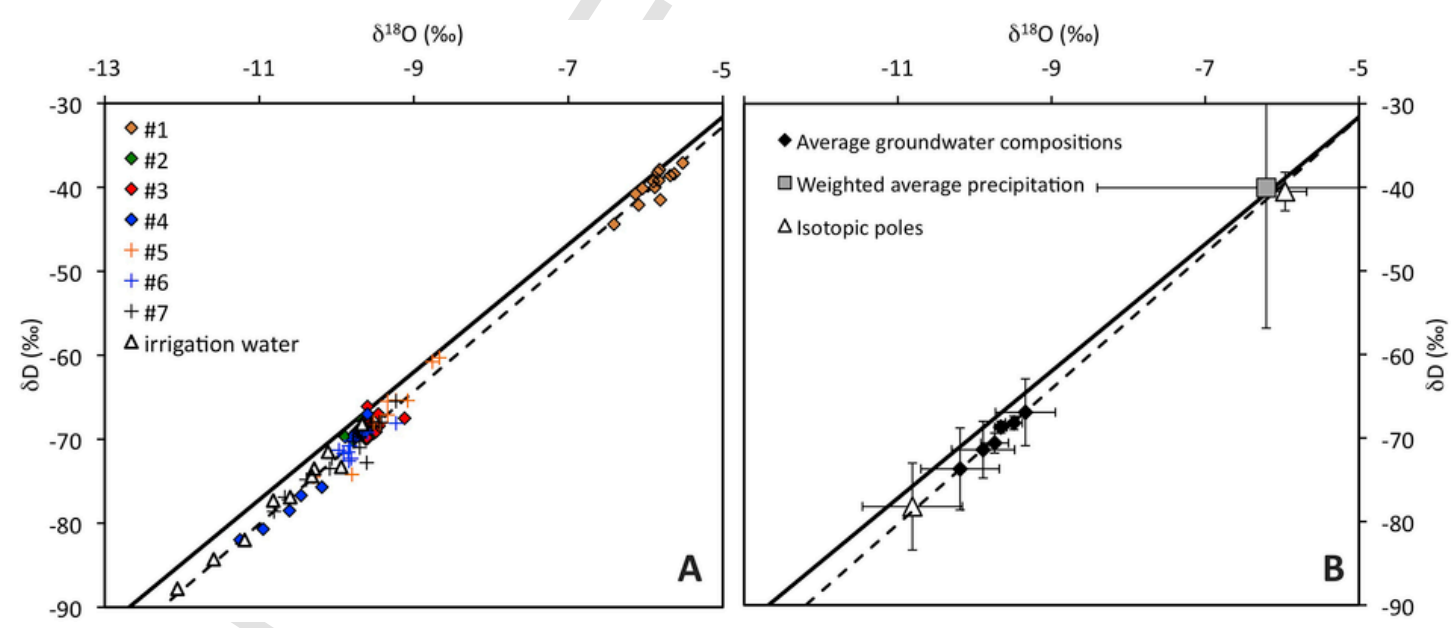

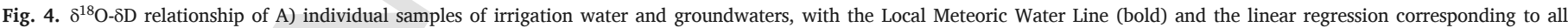

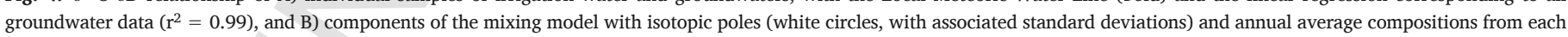

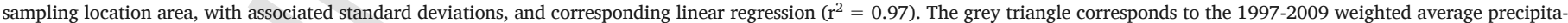
tion composition from the Avignon GNIP station.

Durance River (Serre-Ponçon reservoir), thus the most depleted water, corresponding to spring thaw, is released during summer, when water demand is the highest.

With regards to chloride concentrations, groundwater from \#1 was the least concentrated. Irrigation water was more concentrated than groundwater sampled in $\# 1$, but less concentrated than groundwater from $\# 2$, \#3, and \#6, which also display the lowest seasonal variations. The other groundwater sampling locations displayed more variable $\left[\mathrm{Cl}^{-}\right]$, with values alternatively higher or lower than irrigation water (Table 1, Fig. 3-B). 
Table 1

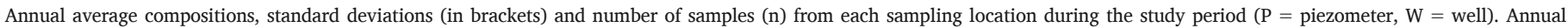
averages are based on daily values interpolated over an annual cycle, in order to account for the irregular sampling time step.

\begin{tabular}{|c|c|c|c|c|c|}
\hline Local identifier & Location \# & Type & $\delta^{18} \mathrm{O}(\% \circ$ vs VSMOW) & $\delta \mathrm{D}(\% \circ$ vs VSMOW) & {$\left[\mathrm{Cl}^{-}\right]\left(\mathrm{mg} \cdot \mathrm{L}^{-1}\right)$} \\
\hline Coussoul & 1 & $\mathrm{P}$ & $-5.96(0.28) \mathrm{n}=15$ & $-40.5(2.3)$ & $9.1(1.2) \mathrm{n}=14$ \\
\hline 1J Aval & 2 & $\mathrm{P}$ & $-9.66(0.08) n=15$ & $-68.7(0.7)$ & $24.3(1.2) \mathrm{n}=13$ \\
\hline 1J Amont & 3 & $P$ & $-9.49(0.11) \mathrm{n}=11$ & $-68.2(0.8)$ & $23.5(1.1) \mathrm{n}=11$ \\
\hline $6 \mathrm{~N}$ & 4 & $\mathrm{P}$ & $-10.19(0.51) \mathrm{n}=11$ & $-73.7(4.9)$ & $18.8(3.2) \mathrm{n}=13$ \\
\hline Pinède & 5 & $\mathrm{~W}$ & $-9.34(0.39) \mathrm{n}=10$ & $-66.9(4.0)$ & $2.3(5.6) \mathrm{n}=11$ \\
\hline Perret & 6 & $\mathrm{~W}$ & $-9.74(0.18) n=11$ & $-70.6(1.2)$ & $25.8(0.9) \mathrm{n}=10$ \\
\hline St Jean & 7 & $\mathrm{~W}$ & $-9.89(0.41) \mathrm{n}=11$ & $-71.4(3.4)$ & $16.4(2.1) \mathrm{n}=13$ \\
\hline Irrigation water (flux weighted averages) & 8 & canal & $-10.81(0.65) \mathrm{n}=10$ & $-78.2(5.2)$ & $15.7(4.8) \mathrm{n}=9$ \\
\hline
\end{tabular}

\subsection{Isotopic evidence of a two-component mixing}

In the $\delta^{18} \mathrm{O}-\delta \mathrm{D}$ plot, groundwater data plot along a linear trend $\left(\delta \mathrm{D}=7.9 \times \delta^{18} \mathrm{O}+6.6 ; \mathrm{r}^{2}=0.99\right)$, which crosses, on one side, the average composition of regional precipitation, and on the other side the composition of irrigation water (Fig. 4-A). The robust alignment of data between the compositions of the two water masses involved in groundwater recharge indicates that groundwater isotopic compositions clearly reflect a pure mixing process, with no substantial influence of subsequent evaporation. The composition of the two end-members: the "natural recharge", coming from the infiltration of local precipitation and the "irrigation recharge", coming from irrigation return flows, was previously established (Séraphin et al., 2016), and is shortly described here. The isotopic composition of natural recharge $\left(\delta_{n}\right)$ was given by the average composition of groundwater sampled in piezometer \#1 $\left(\delta^{18} \mathrm{O}=-5.96 \% \circ \pm 0.28 \% \circ\right.$ and $\delta \mathrm{D}=-40.5 \% \circ \pm 2.29 \%$; Table 1$)$, which was similar to the weighted average precipitation composition of the neighbouring GNIP station (Fig. 4-B). This piezometer is located in a non-irrigated area where the aquifer is very thin (Albinet et al., 1969). In addition, the substratum height $(59.2 \mathrm{~m}$ a.s.l. According to the borehole $\log$ ) is above the piezometric heights around, except for \#4 which displayed a higher water level during the irrigation season (Fig. 2), but the two areas are separated by an outcrop of the Miocene underlying formation (Fig. 1). Therefore, piezometer \#1 is located in an area isolated from the general groundwater flow, and not influenced by irrigation return flows. The isotopic composition of irrigation recharge $\left(\delta_{i}\right)$ was given by the average composition of irrigation water. To account for the modulation of irrigation supply during the season, we used irrigation fluxes (as a percentage of the maximum flux) to calculate a weighted average. This gives $\delta^{18} \mathrm{O}=-10.81 \% \circ \pm 0.65 \%$ and $\delta \mathrm{D}=-78.2 \% \circ \pm 5.2 \%$, which is very close to the arithmetic average. Irrigation water data matches the linear trend of groundwater compositions, indicating that, as observed for the infiltration of local precipitation, there is no modification in the water isotopic composition by evaporation during groundwater recharge.

\section{Methodology}

\subsection{Isotopic mixing model along streamlines}

The mixing proportions of water originating from irrigation return flows $\left(\mathrm{x}_{\mathrm{i}}\right)$ and natural recharge $\left(x_{n}=1-x_{i}\right)$ can be estimated from a simple isotope mass balance:

$x_{i}=\left(\delta_{m}-\delta_{\mathrm{n}}\right) /\left(\delta_{i}-\delta_{\mathrm{n}}\right)$

where $\delta_{m}$ is the groundwater isotopic composition, $\delta_{n}$ is the isotopic composition of the natural recharge, and $\delta_{i}$ is the isotopic composition of the irrigation recharge. The use of a two-component mixing model implies a constant isotopic composition for the two end-members. The 2008-2009 annual averages, are assumed to represent their long-term composition. For the natural recharge end-member $\left(\delta_{n}\right)$, this assumption is supported by the small monthly variations observed in piezometer \#1 (Table 1), and by the similarity with the 1997-2009 weighted average composition of precipitation, suggesting a buffering effect. For the irrigation recharge end-member $\left(\delta_{i}\right)$, a more recent sampling campaign provided a similar average composition for the 2014 irrigation season $\left(\delta^{18} \mathrm{O}=-10.89 \pm 0.79 \%\right.$; $\delta \mathrm{D}=-78.23 \pm 6.24 \%$ o $(\mathrm{n}=7)$, Séraphin et al., 2016). Therefore, the possible inter-annual variations are assumed to remain lower than the standard deviation calculated for the 2009 irrigation season.

In order to interpret these mixing proportions in terms of fluxes, the flowpath corresponding to each groundwater sampling location is considered. Upstream streamlines are thus drawn as up-gradients lines (Fig. 5-B). As illustrated in Fig. 5-A, at steady state, and in the absence of substantial water withdrawal along a streamline, the local groundwater flow $\left(\mathrm{Q}\right.$, in $\mathrm{m}^{2} \mathrm{~s}^{-1}$, i.e. $\mathrm{m}^{3} \mathrm{~s}^{-1}$ per meter width perpendicular to the flow direction), equals the recharge occurring over the stream line, i.e. the sum of both natural $\left(Q_{n}=L_{t} \times R_{n}\right)$ and irrigated recharges $\left(Q_{i}=L_{i} \times\right.$ $R_{i}$ ), leading to the following water balance equation:

$Q=L_{t} \times R_{n}+L_{i} \times R_{i}$

where $\mathrm{L}_{\mathrm{t}}$ is the length of the flux line $(\mathrm{m})$ and $\mathrm{L}_{\mathrm{i}}$ is the length of this flow line covered by irrigated meadows $(\mathrm{m})$. In this equation, the rates of natural and irrigated recharges $\left(R_{n}\right.$ and $R_{i}$, in $\left.\mathrm{m} \mathrm{s}^{-1}\right)$ correspond to net recharge rates, i.e. infiltration minus evapotranspiration, and assumed time invariant and homogeneous over their respective lengths, though the natural recharge rate over irrigated surface may differ from non-irrigated surfaces, because of different soil properties and evapotranspiration rates. Assuming that the summer evapotranspiration mainly affect irrigation water and should not have much impact on the natural recharge rates, which mainly occurs during the non-irrigated period, this difference is neglected and we consider an average value of $R_{n}$, encompassing both irrigated and non-irrigated surfaces. In addition, this 1-D reasoning assumes that advection is the major mass transport process, over dispersion, which is consistent with the aquifer transverse dispersion coefficient $(1.1 \mathrm{~m}$ ) tenfold lower than the longitudinal dispersion (11 m; Séraphin, 2016).

The corresponding isotope mass balance is:

$\delta_{m} \times Q=\delta_{n} \times L_{t} \times R_{n}+\delta_{i} \times L_{i} \times R_{i}$

Eq. (3) implies a good vertical mixing, and an average isotopic composition $\left(\delta_{m}\right)$ representative of the steady state. The ability of the local average composition $\delta_{m}$ to represent the mixing process over the flowpath depends on the average residence time. Considering the short average residence time of the Crau aquifer, the inter-annual reproducibil- 


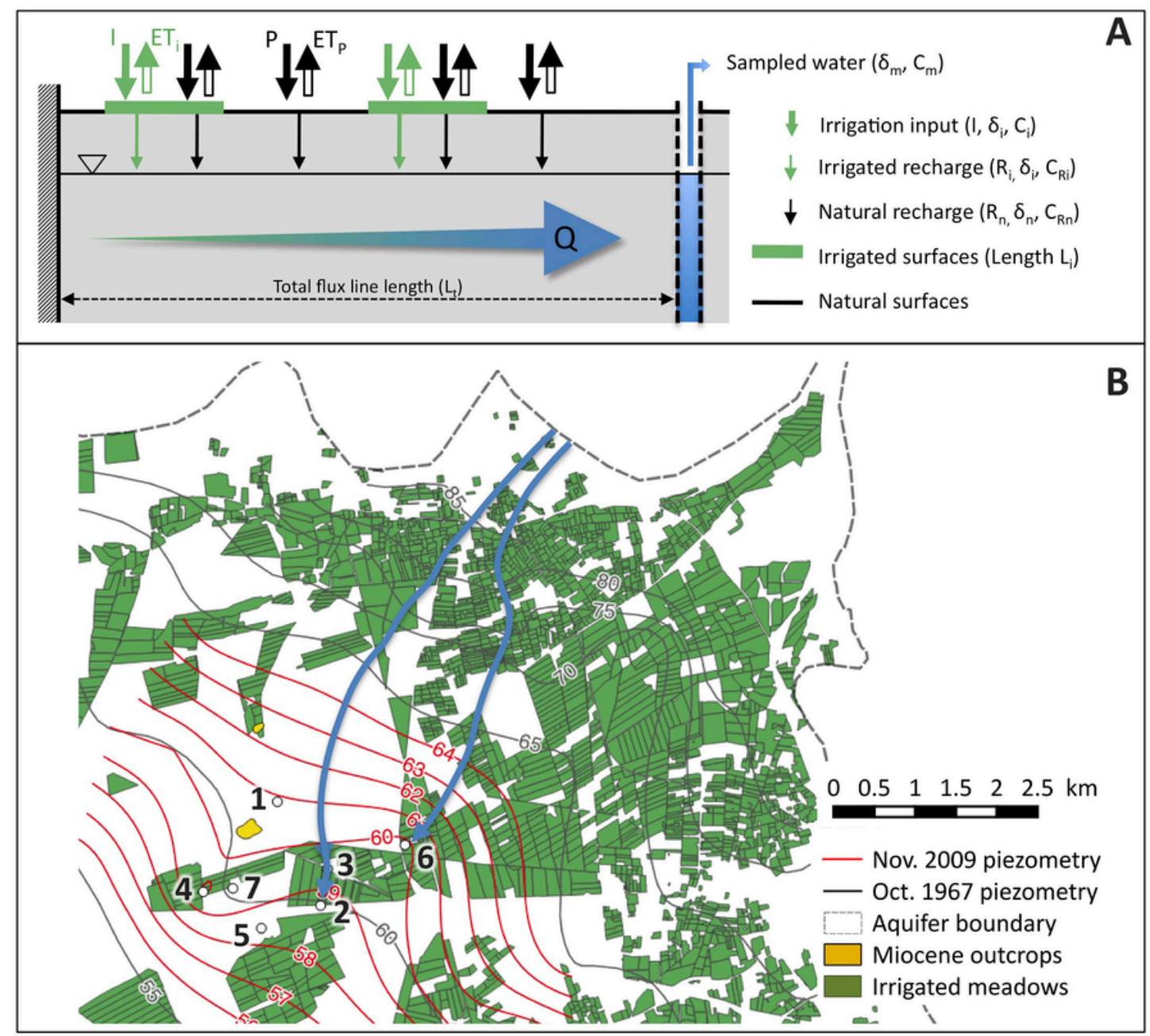

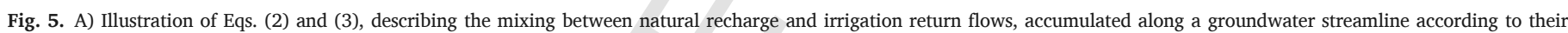
respective corresponding lengths, and B) corresponding upstream streamlines.

ity of the piezometric seasonal pattern (see section 3.2), the interannual stability of groundwater isotopic composition (Séraphin et al., 2016), and the strong seasonality of recharge rates, $\delta_{m}$ is estimated from the average value over an annual period.

Combining Eqs. (2) and (3), and introducing the density of irrigated meadows $A=L_{i} / L_{t}$, the ratio of natural to irrigated recharge is:

$R_{n} / R_{i}=A \times\left(\delta_{i}-\delta_{m}\right) /\left(\delta_{m}-\delta_{n}\right)$

Once established this flux ratio, only one recharge rate is required, either $R_{n}, R_{i}$, or the total recharge, to assess the others.

\subsection{Chloride mass balances}

The application of the chloride mass balance method to quantify surface recharge uses the concentration effect induced by evapotranspiration. It assumes that, at steady state, the chloride dissolved in groundwater originates solely from the surface water, i.e. generally atmospheric inputs, and that only surface runoff may export Chloride. Since surface runoff is negligible in the Crau plain (as suggested by the high permeability of the soils and by the absence of a natural drainage network), all the chloride flux concentrates in groundwater recharge, following the surface water and chloride mass balances equations:

$R_{n}=P-E T_{P}$
$R_{n} \times C_{R n}=F_{a}$

Where $P$ and $E T_{P}$ are the annual rates of precipitation and evapotranspiration of rainfall water, $C_{R n}$ is the concentration of natural recharge flux ( $\mathrm{mg} \mathrm{L}^{-1}$ ), which, at steady state, corresponds to the groundwater composition, and $F_{a}$ is the annual rate of atmospheric chloride inputs (mg $\mathrm{m}^{-2} \mathrm{yr}^{-1}$ ), which corresponds to the sum of chloride brought by rainfall water and dry deposition. In the absence of a local record of atmospheric chloride inputs, data from a neighbouring survey performed in Avignon between October 1997 and March 1999 (Celle-Jeanton et al., 2009) are used, and discussed.

When focusing on irrigation return flows, in which chloride is supplied by irrigation water, the same mass balance approach can be applied to estimate a return flow coefficient:

$R_{i}=I-E T_{I}$

$R_{i} / I=C_{i} / C_{R i}$

Where $I$ is the annual irrigation water supply ( $\mathrm{mm} \mathrm{yr}^{-1} \mathrm{ETI}$ is the evapotranspiration of irrigation water, $C_{i}$ and $C_{R i}$ the chloride concentrations of irrigation water and return flow respectively. There is an explicit difference between evapotranspiration of precipitation (in Eq. (5)) and evapotranspiration of irrigation water (in Eq. (7)), which may be tricky to decipher. However, there is in fact no need to account for 
these detailed evapotranspiration processes since this approach focus on net groundwater recharge.

The chloride concentration of return flow $\left(C_{R i}\right)$ cannot be measured directly, because of the mixing between natural recharge and return flow. However, it can be estimated from the measured groundwater concentration $\left(C_{m}\right.$, in $\left.\mathrm{mg} \mathrm{L}^{-1}\right)$ using the mixing proportion ( $x_{i}$ from Eq. (1)) given by stable isotopes of water as follows:

$C_{R i}=\left(C_{m}-\left(1-x_{i}\right) C_{R n}\right) / x_{i}$

In the Crau aquifer, there is no other substantial chloride source than surface inputs, and it is assumed that agricultural practices do not provide chloride in addition to what is naturally present in irrigation water. The local hay production is controlled and regulated (see section 2.2), and only limited quantities of Nitrogen fertilisers are allowed. Since there is neither the effect of deep evapotranspiration, i.e. after groundwater recharge, nor additional chloride sources able to enrich groundwater concentration compared to the recharge flux, and because the aquifer is considered at steady-state, the concentration of the recharge fluxes can be estimated from annual average groundwater compositions. The chloride concentration of "natural recharge" $\left(C_{R n}\right)$ was measured in piezometer \#1, which represents the pure natural end-member in the isotopic mixing model $\left(x_{i}=0\right)$. Then, the combination of Eqs. (1), (8) and (9) allows the calculation of an average return flow coefficient $R_{i} / I$, along a streamline, knowing $C_{i}, C_{n}, C_{m}, \delta_{i}, \delta_{n}$, and $\delta_{m}$.

\subsection{The water table fluctuation method}

Fully independent from the geochemical approach, the Water Table Fluctuation method (WTF) was applied to Piezometer \#2, to calculate a daily recharge time series over the 2003-2009 period. The daily water table level recorded in piezometer \#2 is neither influenced by water abstraction, nor by evapotranspiration from the water table. Located at the downstream border of an irrigated field, water table fluctuations only reflect the influence of both natural and irrigated recharges.

The WTF method is commonly used due to its simplicity, and a comprehensive review of its theoretical framework and application conditions can be found in Healy and Cook (2002). It basically assumes that an observed water level rise $\Delta h(\mathrm{~m})$ during a given time period $\Delta t(\mathrm{~s})$ results from the balance between the recharge $\mathrm{R}\left(\mathrm{m} \mathrm{s}^{-1}\right)$ and the net groundwater drainage $\mathrm{D}\left(\mathrm{m} \mathrm{s}^{-1}\right)$, as follows:

$(\Delta h / \Delta t) \times S_{y}=R+D$

where $S_{y}$ is the specific yield, and the net groundwater drainage (D) is the difference between lateral inflows and outflows. Following Crosbie et al. (2005), D can be estimated by measuring the water table variations during a period deprived of recharge $\left(h_{d}\right)$ using the following ex- pression:

$D=\left(\Delta h_{d} / \Delta t\right) \times S_{y}$

Among the different ways to derive the required value of $S_{y}$, a local in situ estimate can be obtained from Eq. (10), using an isolated recharge event, if the recharge is known. Combining Eqs. (10) and (11) gives:

$S_{y}=R /\left(\Delta h / \Delta t-\Delta h_{d} / \Delta t\right)$

where $\Delta h_{d}$ corresponds to the water table variation which would occur without recharge during the $\Delta t$ period.

\section{Results}

\subsection{Recharge rates from the combined isotope and chloride mass balances}

Annual averages of $\delta_{m}$ and $C_{m}$ were calculated from daily values linearly interpolated between measured data, over a complete annual cycle, in order to account for the irregular sampling time step (Table 1). For each sampling location, the density of irrigated meadows (A) was defined along the corresponding streamline (Fig. 5-B, Table 2). Mixing proportions $\left(\mathrm{x}_{\mathrm{i}}\right)$ vary between $70 \%$ and $87 \%$, and between $70 \%$ and $88 \%$ using $\delta^{18} \mathrm{O}$ and $\delta \mathrm{D}$, respectively (Table 2 ). The highest proportion of irrigation water was found in \#4, which also displays the most variable isotopic composition. For all sampling points, the good consistency between proportions obtained from both isotopic species comes from the robust alignment of data between the two isotopic poles (Fig. 4-B), and in the following, only $\delta^{18} \mathrm{O}$ results will be discussed.

Sampling points \#2, \#3, and \#6 are located downstream to well defined stream lines starting at the upstream aquifer limit (Fig. 5-B). Despite different streamline lengths and irrigated meadow densities, consistent values of recharge proportion were found using the isotopic mixing model (Eq. (4)): $R_{n} / R_{i}=0.13$ (Table 2). This proportion is in line with the global average obtained for the entire aquifer $\left(R_{n} / R_{i}=0.12 \pm 0.05\right.$, Séraphin et al., 2016). On the other hand, sampling points \#4, \#5 and \#7 are located in the hydraulic shadow of an outcrop of the Miocene underlying layer (Fig. 5-B). On this Miocene outcrop, a little pond $\left(<5000 \mathrm{~m}^{2}\right)$ is forming seasonally, fed by an irrigation canal. This water infiltrates continuously towards the water table during the irrigation season, and may explain the location of the piezometric mound (Fig. 1). Therefore, the very low $R_{n} / R_{i}$ values obtained for \#4 and \#7 (Table 2) are due to some overestimation of $R_{i}$.

Applying Eqs. (8) and (9) with the average concentration of irrigation water for $C_{i}$, we found $R_{i} / I$ values varying from $0.51 \pm 0.16$ to $0.86 \pm 0.26$ (Table 2). The high values obtained for \#4, \#7 are consistent with the occurrence of an irrigation mound. Considering $\# 2$, \#3 and \#6 as more spatially representative, an average value of $0.53 \pm 0.16$ is proposed for the return flow coefficient in this upstream part of the Crau aquifer. The average flows of irrigation water brought

Table 2

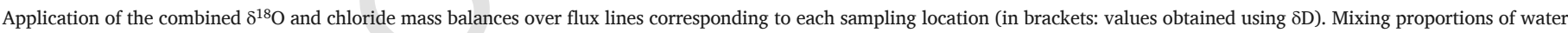

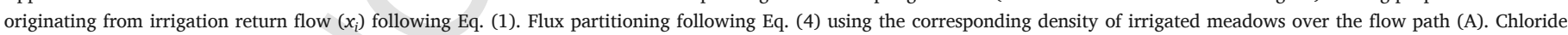

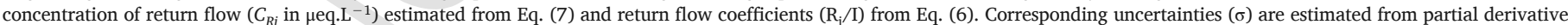
calculations.

\begin{tabular}{|c|c|c|c|c|c|c|c|c|c|c|}
\hline Location \# & $\mathrm{X}_{\mathrm{i}}$ & $\sigma_{(\mathrm{xi})}$ & A & $\sigma_{(\mathrm{A})}$ & $\mathrm{R}_{\mathrm{n}} / \mathrm{R}_{\mathrm{i}}$ & $\sigma_{(\mathrm{Rn} / \mathrm{Ri})}$ & $\mathrm{C}_{\mathrm{Ri}}$ & $\sigma_{(\mathrm{CRi})}$ & $\mathrm{R}_{\mathrm{i}} / \mathrm{I}$ & $\sigma_{(\mathrm{Ri} / \mathrm{l})}$ \\
\hline 2 & $0.76(0.75)$ & $0.10(0.11)$ & 0.41 & 0.02 & 0.13 & 0.07 & 28.9 & 5.7 & 0.54 & 0.16 \\
\hline 3 & $0.73(0.73)$ & $0.10(0.11)$ & 0.38 & 0.02 & 0.13 & 0.07 & 28.8 & 5.8 & 0.54 & 0.17 \\
\hline 4 & $0.87(0.88)$ & $0.12(0.12)$ & 0.27 & 0.02 & 0.04 & 0.04 & 20.2 & 4.3 & 0.78 & 0.24 \\
\hline 5 & $0.70(0.70)$ & $0.10(0.10)$ & 0.23 & 0.02 & 0.10 & 0.05 & 28.0 & 5.8 & 0.56 & 0.17 \\
\hline 6 & $0.78(0.80)$ & $0.11(0.11)$ & 0.47 & 0.02 & 0.13 & 0.08 & 30.5 & 5.8 & 0.51 & 0.16 \\
\hline 7 & $0.81(0.82)$ & $0.11(0.12)$ & 0.18 & 0.02 & 0.04 & 0.03 & 18.1 & 4.1 & 0.86 & 0.26 \\
\hline
\end{tabular}


to the regional meadows is $I=2250 \pm 250 \mathrm{~mm} \mathrm{yr}^{-1}$, leading to $R_{i}=1190 \pm 380 \mathrm{~mm} \mathrm{yr}^{-1}$.

In addition, a exploratory evaluation of the natural recharge rate was performed using the classical application of the chloride mass balance method, Eq. (6), based on a continuous monitoring of atmospheric inputs performed in Avignon between October 1997 and March 1999 (Celle-Jeanton et al., 2009), which estimated an atmospheric chloride input of $975 \mathrm{mg} \mathrm{m}^{-2} \mathrm{yr}^{-1}$, of which $24 \%$ is supplied by dry deposition. This value combined with the average chloride concentration measured in piezometer $\# 1$ led to $R_{n}=110 \pm 10 \mathrm{~mm} \mathrm{yr}^{-1}$. Nevertheless, strong gradients have been observed in coastal areas (Alcala and Custodio, 2008; Bresciani et al., 2014; Jaunat et al., 2013; Ladouche et al., 2009; Naranjo et al., 2015). Our study area, closer to the shoreline $(\approx 30-40 \mathrm{~km})$ than the Avignon station $(\approx 60 \mathrm{~km})$, may thus be affected by higher sea-salt inputs. Taking the Avignon atmospheric record as a lower limit, and assuming a possible underestimation of up to $50 \%$, a possible range of $R_{n}$ between $\approx 110 \mathrm{~mm} \mathrm{yr}^{-1}$ and $\approx 160 \mathrm{~mm} \mathrm{yr}^{-1}$ seems reasonable.

\subsection{Recharge estimates from water table fluctuations}

The estimate of $S_{y}$ was based on the water table response to an extreme rainfall event, interpreted using Eq. (12). In December 2003, a total rainfall of over $100 \mathrm{~mm}$ occurred in less than $30 \mathrm{~h}$, causing severe damage in the neighbouring city of Arles. The water level responded within less than 2 days to the precipitation. The entire amount of precipitation was assumed to contribute to groundwater recharge because the saturated conductivity of the soil $\left(>1.10^{-6} \mathrm{~m} \mathrm{~s}^{-1}\right.$ in this field; Bader et al., 2010) is higher than the precipitation rate. In addition, the antecedent soil water conditions were expected to prevent any significant soil water retention for two reasons: the cumulated amount of precipitation during the preceding 30-day period $(79 \mathrm{~mm})$ was almost similar to the height of the maximum soil water storage capacity ( $86 \mathrm{~mm}$ estimated in this specific field, Merot et al. (2008)), and the linear shape of water table level evolution before the abrupt rise showed that the aquifer was not recharged by the rainfall episodes preceding the main event (Fig. 6). Assuming that the total amount of precipitation measured at the neighbouring station, located $1 \mathrm{~km}$ far from \#2, contributed to the groundwater level rise, a total recharge $\mathrm{R}=141 \pm 10 \mathrm{~mm}$ was considered, the estimated uncertainty being mainly attributed to possible water retention in the vadose zone. The slope of the water level drop $\left(\Delta h_{d} / \Delta t\right)$ before the infiltration event was used to isolated the purely vertical infiltration signal, which gave $\Delta h$ $\Delta h_{d}=1.79 \mathrm{~m}$ over a period of 50 days, sufficient to recover the prior drop rate (Fig. 6). Note that a 40-day period corresponds to a $1.74 \mathrm{~m}$ rise, thus $\Delta h-\Delta h_{d}$ is weakly sensitive to the precise $\Delta t$. Taking $\Delta h$ $\Delta h_{d}=1.79 \pm 0.05 \mathrm{~m}$, we obtained $\mathrm{S}_{\mathrm{y}}=0.079 \pm 0.006$. This value is in line with the only two estimates previously available in the study area (pumping tests): 0.06 and 0.11 , and consistent with the heterogeneous nature of the alluvial deposits, in which pebbles sometimes larger than $10 \mathrm{~cm}$ are mixed with sands and clays.

To determine the net groundwater drainage $\mathrm{D}$, the longest periods deprived of recharge were isolated using the following criteria: 1) a beginning 14 days after the last substantial rainfall; 2) only small $(<10 \mathrm{~mm})$ isolated rainfall episodes during the period; and 3) a minimum duration of 30 days (Fig. 7-A and B). Three periods were selected, leading to an average value of $\Delta h_{d} / \Delta t=-49.70 \pm 1.66 \mathrm{~mm}^{\text {day }}{ }^{-1}$, very similar to the piezometric level decline rate observed prior to the 2003 high rainfall-recharge $\left(\Delta h_{d} / \Delta t=-51.3 \mathrm{~mm} \mathrm{day}^{-1}\right)$. No evident dependence of these recession rates on the water level was observed, which supports the assumption of a constant lateral drainage, following the theory described by Cuthbert (2014). Then, applying Eq. (11) with $\mathrm{S}_{\mathrm{y}}=0.079 \pm 0.006$, it yields $D=-3.91 \pm 0.33 \mathrm{~mm} \mathrm{day}^{-1}$.

Finally, a daily time series of recharge rates was calculated, assuming a constant net discharge $\mathrm{D}$, using the following equation:

$$
R_{i}+R_{n}=\Delta h / \Delta t \times S_{\mathrm{y}}-D
$$

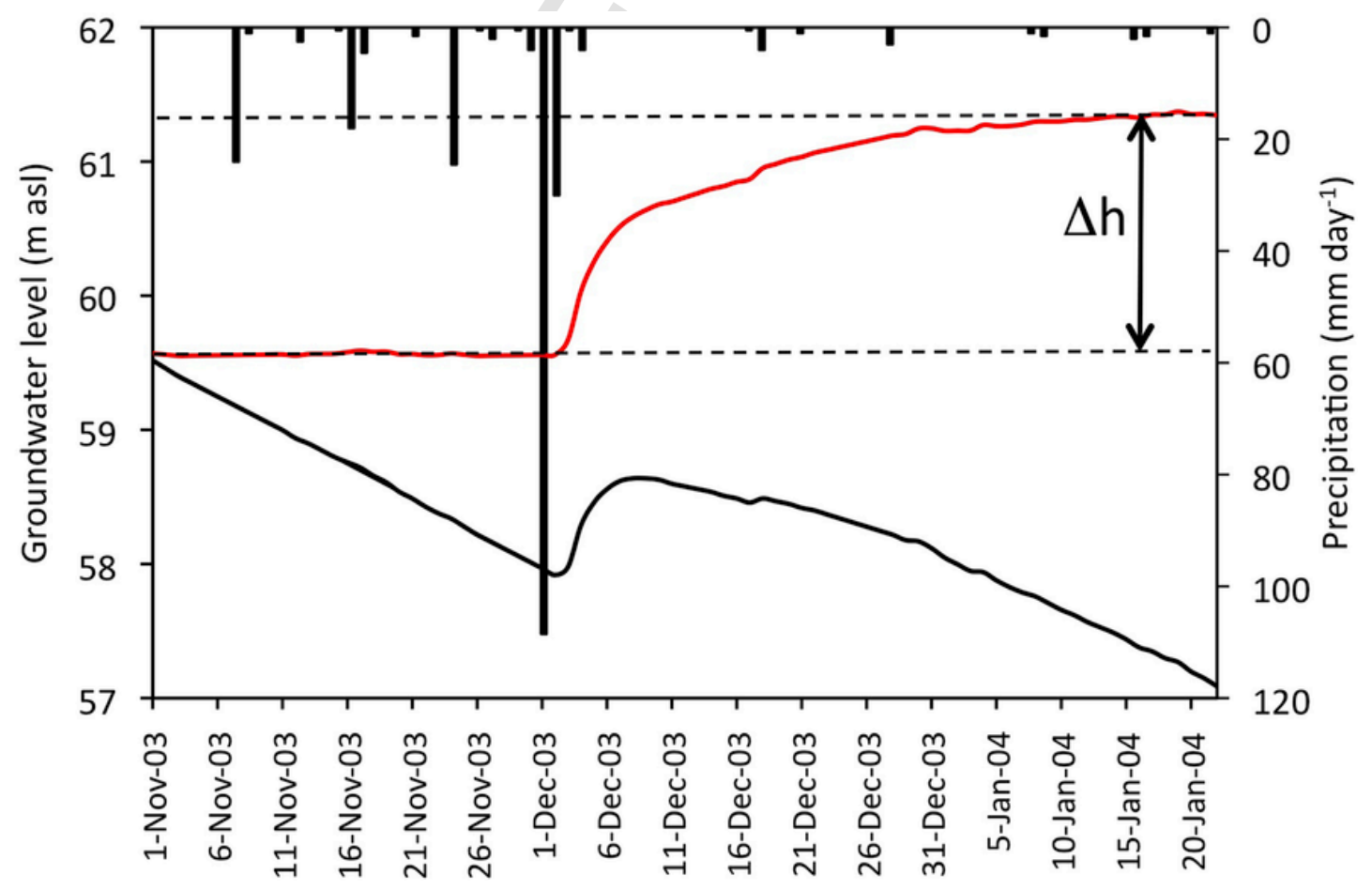

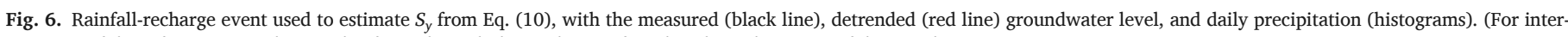
pretation of the references to colour in this figure legend, the reader is referred to the web version of this article.) 

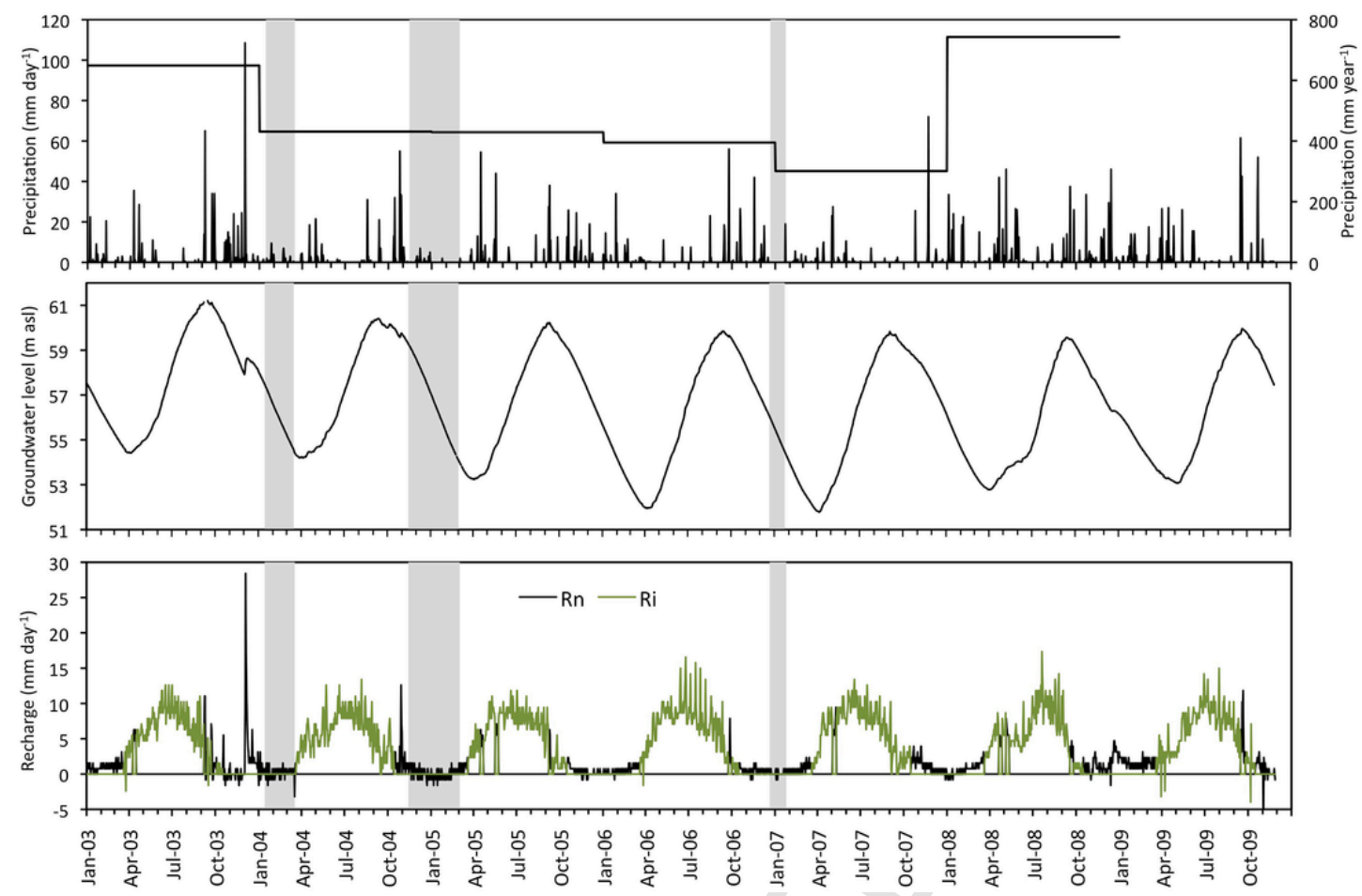

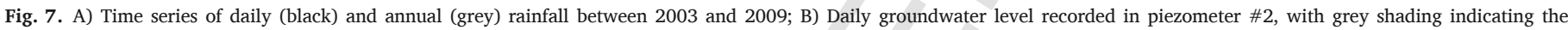
non-recharge periods used to estimate D from Eq. (9); C) Corresponding daily recharge rates calculated from Eq. (11).

The partitioning of $R_{n}$ and $R_{i}$, was based on the timing of irrigation periods: $R_{i}=0$ during the non-irrigated periods, and $R_{n}=0$ during the irrigated period. This approach implies to consider that the response delays during transitions between irrigated and non-irrigated periods (and conversely) compensate each other. Irrigation periods were based on practical irrigation rules, as follows: 1) the default irrigation period is from March 20th to October 15th; 2) in the event of rainfall $>30 \mathrm{~mm}$ day $^{-1}$ during March, the beginning of irrigation is delayed by 7 days after the rain event; 3 ) in the event of precipitation $>30 \mathrm{~mm}$ during October, irrigation is assumed to end; and 4) during the irrigation period, each rainfall event $>30 \mathrm{~mm}$ day $^{-1}$ leads to an interruption of irrigation during 7 days. Exceptionally, the 2007 irrigation period extended after mid-October because of dry summer conditions (Fig. 7-A). We have thus attributed to irrigation return flow the total recharge of $67 \mathrm{~mm}$, which occurred between mid-October and the first substantial autumn rainfall (November 21st). The resulting daily recharge time series displays a progressive shape during irrigation periods (Fig. 7-C), slightly shifted compared to the sharp water level variations (Fig. 7-B). Note that the slighthy negative daily values on Fig. 7-C come from instabilities in the $\Delta h / \Delta t$ rate, but the sum of daily recharge was null during the non-recharge periods. Annual values, inter-annual averages and corresponding standard deviations are shown in Table 3.

\section{Discussion}

\subsection{Analysis of the different flowpaths}

The combination of the chloride mass balance and the isotope mixing model provided return flow coefficients $\left(R_{i} / I\right)$ varying between $0.51 \pm 0.16$ and $0.86 \pm 0.26$ for the different stream lines (Table 2). This high range of return flow coefficients shows the important spatial variations in the study area, as qualitatively suggested by the presence of an irrigation mound in the piezometric map (Fig. 1). On the one hand, the highest return flow coefficients demonstrate the contribution of the irrigation network to the recharge, through the accumulation of irrigation water in a pond, which continuously infiltrates. On the other hand, an average value of 0.53 was found for sampling points \#2, \#3 and \#6, corresponding to the two flowpaths which are the most representative of the upstream part of the Crau aquifer (Fig. 5-B). Using the average irrigation supply, this average return flow coefficient led to a rate of return flow of $1190 \pm 380 \mathrm{~mm} \mathrm{yr}^{-1}$.

Furthermore, combining this return flow rate with recharge proportions established from the isotope mixing model $\left(R_{n} / R_{i}\right)$ provides an average natural recharge rate, $R_{n}=160 \pm 100 \mathrm{~mm} \mathrm{yr}^{-1}$, for these two representative streamlines. Despite its important relative uncertainty,

Table 3

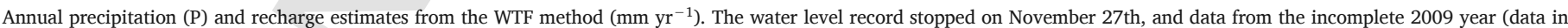
italics) were excluded from the long-term average.

\begin{tabular}{|c|c|c|c|c|c|c|c|c|}
\hline & 2003 & 2004 & 2005 & 2006 & 2007 & 2008 & 2009 & 2003-2008 averages and standard deviations \\
\hline$P$ & 649 & 431 & 429 & 395 & 301 & 743 & 539 & $491 \pm 168$ \\
\hline$R_{i}+R_{n}$ & 1476 & 1358 & 1322 & 1424 & 1484 & 1434 & 1400 & $1416 \pm 64$ \\
\hline$R_{n}$ & 310 & 97 & 140 & 89 & 113 & 259 & 198 & $168 \pm 93$ \\
\hline$R_{i}$ & 1166 & 1261 & 1182 & 1335 & 1370 & 1175 & 1202 & $1248 \pm 89$ \\
\hline$R_{n} / P$ & 0.48 & 0.23 & 0.33 & 0.22 & 0.38 & 0.35 & 0.37 & $0.34 \pm 0.10$ \\
\hline
\end{tabular}


this rate is consistent with the direct and traditional application of the chloride mass balance at piezometer $\# 1 \quad\left(110 \pm 8 \mathrm{~mm} \mathrm{yr}^{-1}\right.$ to $160 \pm 10 \mathrm{~mm} \mathrm{yr}^{-1}$ ), while being independent from any atmospheric chloride data.

\subsection{Residence times and seasonal variations}

The groundwater isotopic composition remains very stable for piezometers \#2, \#3 and \#6, despite the strong seasonality of the entering isotopic signal (seven months per year of irrigation supply). This comes from an efficient mixing and suggests a residence time encompassing at least one complete annual cycle for the corresponding flow lines. Contrastingly, the greater seasonal amplitudes observed for \#4, \#5 and \#7 (Table 1, Fig. 3-A) suggest lower residence times. The average residence time $(T)$ is expressed by $T=S_{y} e /\left(R_{n}+A R_{i}\right)$, with $e$ the saturated thickness. Using the recharge rates obtained for the two main stream lines, the $S_{y}$ value previously estimated for \#2, a saturated thickness estimated at $10 \mathrm{~m}$ for \#2, \#3 and \#6, and $5 \mathrm{~m}$ for \#4, \#5 and \#7 (based on the borehole logs of Piezometers \#1, \#2, \#3, and \#4), the respective recharge rates lead $\mathrm{T} \approx 1.2$ years for the two main stream lines, in line with the average residence time of the whole aquifer. For the shorter stream lines, the residence time drop until $\approx 4$ - 9 months, because of higher recharge rates and smaller aquifer thickness. The magnitude of seasonal isotopic variations reflects the water residence time over the corresponding flow path, and in this high flushing aquifer, a seasonal survey remains essential for the application of these geochemical approaches.

\subsection{Comparison with the WTF results}

The WTF approach is particularly well adapted to the Crau aquifer, because of rapid infiltration in the vadose zone and high seasonal water table variations. It provided local daily recharge rates on a plot typically characterizing a well-functioning irrigated meadow. The mean annual surface recharge was $1420 \pm 120 \mathrm{~mm} \mathrm{yr}^{-1}$ for the 2003-2008 period, with $R_{n}=170 \mathrm{~mm} \mathrm{yr}^{-1}$ and $R_{i}=1250 \mathrm{~mm} \mathrm{yr}^{-1}$, in line with the results of the geochemical mass balances.

In addition, results of the WTF method illustrate the interannual variability of groundwater recharge (Table 3 ). The standard deviation of annual total recharges $\left(60 \mathrm{~mm} \mathrm{yr}^{-1}\right)$ is lower than that of natural and irrigated recharge separately (standard deviations of $90 \mathrm{~mm} \mathrm{yr}^{-1}$ ), which demonstrates the role of irrigation in maintaining a stable groundwater level. Furthermore, the maximum value of annual total recharge $(1480 \mathrm{~mm})$ is observed during the driest year of the period (2007), illustrating that irrigation supply compensates rainfall variations. The strong variations of the natural recharge rate (from $90 \mathrm{~mm} \mathrm{yr}^{-1}$ in 2006 to $310 \mathrm{~mm} \mathrm{yr}^{-1}$ in 2003), are closely related to the variations of annual precipitation, which also explains that the annual minimum groundwater level decreased from 2003 until 2007, as the annual rainfall decreased (Fig. 7A and B). The average recharge efficiency $\left(R_{n} / P\right)$ is $0.34 \pm 0.10$, a value which can be further used in transient groundwater modelling of the aquifer. Note that the high value of $R_{n} / P$ found in 2003 was due to the extreme rainfall event, which accounted for almost half of the annual recharge ( $141 \mathrm{~mm}$, as shown above). In the context of climate change, the expected increased frequency of extreme events may thus have important impacts on natural recharge.

\subsection{Comparison with previous estimates}

Using the combination of stable isotopes, geostatistical simulations and Darcy's flux estimates, we previously estimated the global aquifer water balance (Séraphin et al., 2016). Irrigation return flow represents almost $69 \%$ of the surface recharge, estimated at about $22410^{6} \mathrm{~m}^{3} \mathrm{yr}^{-1}$. Reported to the total area of irrigated meadows, it gives the following average values: $R_{i}=1109 \pm 202 \mathrm{~mm} \mathrm{yr}^{-1}, R_{n}=128 \pm 50 \mathrm{~mm} \mathrm{yr}^{-1}$, corresponding to a recharge ratio $R_{n} / R_{i}=0.12$ and a return flow coefficient $R_{i} / I=0.49$. Although both studies are based on the application of an isotopic mixing framework, the associated flux estimates are 1) fully independents, relying on Darcy's flux on the one hand, and chloride mass balance on the other, and 2) representative of different scales. In this study, important spatial variations are shown, linked with local particularities of the irrigation network. Nevertheless, the stream lines associated to piezometers \#2, \#3, and \#6, discussed as the most representative of the general situation, led to recharge rates which are in line with the whole aquifer.

In addition, different previous studies focused on the assessment of irrigation efficiency. Applying the crop model "STICS", Courault et al. (2010) gave deep infiltration rates $\left(R_{i}\right)$ of $1680 \mathrm{~mm}$ for 2006 in the southern part of the Crau plain, while values above $2200 \mathrm{~mm} \mathrm{yr}^{-1}$ were found for our study area when this crop model was applied at the scale of the whole Crau plain (Olioso et al., 2013). More locally, and using detailed surface flux measurements performed on the irrigated meadow where piezometer \#2 is located, Bader et al. (2010), estimated that soil infiltration represents on average $79 \%$ of the irrigation supply, during a sub-period of the 2004 irrigation season. Nevertheless, the net groundwater recharge remained unknown since water infiltrated in the soil may not reach the water table because of evapotranspiration. On the same plot (Merot et al., 2008), estimated a deep infiltration of $1316 \mathrm{~mm}$ in 2004 and $1461-1916 \mathrm{~mm}$ in 2005.

\section{Conclusions}

The results of the combined geochemical mass balances are consistent with a local daily time series of recharge fluxes derived from the Water Table Fluctuation method over the 2003-2009 period, and with the spatial average previously quantified over the whole aquifer (Séraphin et al., 2016), which demonstrates their relevance. The combination of a chloride mass balance with conservative tracers of mixing processes, namely $\delta^{18} \mathrm{O}$ and $\delta \mathrm{D}$, can thus easily and efficiently provide the rate of infiltrated return flows, based on a seasonal survey of irrigation water concentration.

This study confirms the huge magnitude of irrigation return flows in the North-Eastern part of the Crau plain, and evidences the role of irrigation in maintaining a stable groundwater level. At the scale of the entire aquifer $\left(540 \mathrm{~km}^{2}\right)$, given the total surface covered by irrigated meadows $\left(140 \mathrm{~km}^{2}\right)$, irrigation return flows largely dominate recharge compared to the infiltration of local precipitation, but important spatial variations are evidenced. The groundwater resource is mainly supported by irrigation return flows, nowadays and for several centuries, but this fragile equilibrium is threatened by the increasing urbanisation and water resource shortage, which tends to reduce the areas devoted to flood irrigation, and to increase irrigation efficiency. As is frequently the case in agricultural areas, it remains difficult to obtain detailed data on water consumption, for management purposes. Therefore, geochemical tracers represent an appropriate alternative method, which can be used to quantify return flow coefficient, to estimate their spatial variations, and monitor their time variations.

\section{Uncited references}

Delin et al., 2007; Marechal et al., 2006. 


\section{Acknowledgments}

This work was supported by the CNRS-INSU, through the EC2CO-HYDROCCAM project, and by the SICMED-CRAU Research project. We gratefully thank Montpellier SupAgro, Domaine du Merle, for hosting the field work, and for providing water table data. We also thank P. Dussouillez (CEREGE) who performed the GPS measurements, C. Sonzogni (CEREGE) for her contribution to the isotopic analysis and R. Simler (LHA) for chemical analysis.

\section{References}

Albinet, M., Bonnet, M., Colomb, E., Cornet, G., 1969. Istres-Eyguière, Plaine de la Crau. BRGM. In: Carte hydrogéologique de la France 1/50000. BRGM.

Alcalá, F.J., Custodio, E., 2014. Spatial average aquifer recharge through atmospheric chloride mass balance and its uncertainty in continental Spain. Hydrol. Process 28, 218-236.

Alcalá, F.J., Custodio, E., 2008. Atmospheric chloride deposition in continental Spain. Hydrol. Process 22, 3636-3650.

Bader, J.C., Saos, J.L., Charron, F., 2010. Model of border irrigation runoff, advance and infiltration on a soil covering a very permeable subsoil. Hydrol. Sci. Journal-Journal Des. Sci. Hydrol. 55 (2), 177-191.

Blasch, K.W., Bryson, J.R., 2007. Distinguishing sources of ground water recharge by using delta H-2 and delta O-18. Ground Water 45 (3), 294-308.

Bresciani, E., Ordens, C.M., Werner, A.D., Batelaan, O., Guan, H., Post, V.E.A., 2014. Spatial variability of chloride deposition in a vegetated coastal area: implications for groundwater recharge estimation. J. Hydrol. 519, 1177-1191.

Buisson, E., Dutoit, T., 2006. Creation of the natural reserve of La Crau: implications for the creation and management of protected areas. J. Environ. Manage 80, 318-326.

Celle-Jeanton, H., Travi, Y., Loye-Pilot, M.-D., Huneau, F., Bertrand, G., 2009. Rainwater chemistry at a Mediterranean inland station (Avignon, France): local contribution versus long-range supply. Atmos. Res. 91 (1), 118-126.

Courault, D., Hadria, R., Ruget, F., Olioso, A., Duchemin, B., Hagolle, O., Dedieu, G., 2010. Combined use of FORMOSAT-2 images with a crop model for biomass and water monitoring of permanent grassland in Mediterranean region. Hydrology Earth Syst. Sci. 14 (9), 1731-1744.

Crosbie, R.S., Binning, P., Kalma, J.D., 2005. A time series approach to inferring groundwater recharge using the water table fluctuation method. Water Resour. Res. 41 (1).

Cruz-Fuentes, T., Heredia, J., Cabrera, M.C., Custodio, E., 2014. Behaviour of a small sedimentary volcanic aquifer receiving irrigation return flows: La Aldea, Gran Canaria, Canary Islands (Spain). Hydrogeol. J. 22, 865-882. https://doi.org/10.1007/ s10040-013-1094-9.

Cuthbert, M.O., 2014. Straight thinking about groundwater recession. Water Resour. Res. 50 (3), 2407-2424.

Dassi, L., 2011. Use of chloride mass balance and tritium data for estimation of groundwater recharge and renewal rate in an unconfined aquifer from North Africa: a case study from Tunisia. Environ. Earth Sci. 60 (4), 861-871.

Delin, G.N., Healy, R.W., Lorenz, D.L., Nimmo, J.R., 2007. Comparison of local-to regional-scale estimates of ground-water recharge in Minnesota, USA. J. Hydrol. 334, 231-249.

Dewandel, B., Gandolfi, J.-M., De Condappa, D., Ahmed, S., 2008. An efficient methodology for estimating irrigation return flow coefficients of irrigated crops at watershed and seasonal scale. Hydrol. Process 22, 1700-1712.

Duque, C., López-Chicano, M., Calvache, M.L., Martín-Rosales, W., Gómez-Fontalva, J.M., Crespo, F., 2011. Recharge sources and hydrogeological effects of irrigation and an influent river identified by stable isotopes in the Motril-Salobreña aquifer (Southern Spain). Hydrol. Process 25, 2261-2274.

Edmunds, W.M., Fellman, E., Goni, I.B., Prudhomme, C., 2002. Spatial and temporal distribution of groundwater recharge in northern Nigeria. Hydrogeology J. 10 (1), 205-215.

Edmunds, W.M., Gaye, C.B., 1994. Estimating the spatial variability of groundwater recharge in the Sahel using chloride. J. Hydrology 156 (1-4), 47-59.

Eriksson, E., Khunakasem, V., 1969. Chloride concentration in groundwater, recharge rate and rate of deposition of chloride in the Israel Coastal Plain. J. Hydrol. 7, 178-197.

Gates, J.B., Edmunds, W.M., Ma, J.Z., Scanlon, B.R., 2008. Estimating groundwater recharge in a cold desert environment in northern China using chloride. Hydrogeology J. 16 (5), 893-910.

Gonçalvès, J., Vallet-Coulomb, C., Petersen, J., Hamelin, B., Deschamps, P., 2015. Declining water budget in a deep regional aquifer assessed by geostatistical simulations of stable isotopes: case study of the Saharan Continental Intercalaire. J. Hydrology 531, $821-829$

Guglielmi, Y., Mudry, J., Blavoux, B., 1998. Estimation of the water balance of alluvial aquifers in region of high isotopic contrast: an example from southeastern France. J. Hydrology 210 (1-4), 106-115.
Harrington, G.A., Cook, P.G., Herczeg, A.L., 2002. Spatial and temporal variability of ground water recharge in central Australia: a tracer approach. Ground Water 40, 518-527.

Healy, R.W., Cook, P.G., 2002. Using groundwater levels to estimate recharge. Hydrogeology J. 10 (1), 91-109.

IAEA, 2009. Reference Sheet for VSMOW2 and SLAP2 International Measurement Standards.

IAEA/WMO, 2016. GNIP. Global Network for Isotopes in Precipitation.

Jasechko, S., et al., 2014. The pronounced seasonality of global groundwater recharge. Water Resour. Res. 50 (11), 8845-8867.

Jaunat, J., Celle-Jeanton, H., Huneau, F., Dupuy, A., Le Coustumer, P., 2013. Characterisation of the input signal to aquifers in the French Basque Country: emphasis on parameters influencing the chemical and isotopic composition of recharge waters. J. Hydrology 496, 57-70.

Jiménez-Martínez, J., Candela, L., Molinero, J., Tamoh, K., 2010. Groundwater recharge in irrigated semi-arid areas: quantitative hydrological modelling and sensitivity analysis. Hydrogeol. J. 18, 1811-1824.

Kendy, E., Zhang, Y.Q., Liu, C.M., Wang, J.X., Steenhuis, T., 2004. Groundwater recharge from irrigated cropland in the north China plain: case study of luancheng county, Hebei province, 1949-2000. Hydrol. Process. 18 (12), 2289-2302.

Ladouche, B., Aquilina, L., Nathalie, D., 2009. Chemical and isotopic investigation of rain water in Southern France (1996-2002): potential use as input signal for karst functioning investigation. J. Hydrology 367 (1-2), 150-164.

Liu, C.-W., Tan, C.-H., Huang, C.-C., 2005. Determination of the magnitudes and values for groundwater recharge from Taiwan's paddy field. Paddy Water Environ. 3 (2), 121-126.

Liu, Y.P., Yamanaka, T., 2012. Tracing groundwater recharge sources in a mountain-plain transitional area using stable isotopes and hydrochemistry. J. Hydrology 464, $116-126$.

Mailhol, J.C., Merot, A., 2008. SPFC: a tool to improve water management and hay production in the Crau region. Irrig. Sci. 26, 289-302. https://doi.org/10.1007/ s00271-007-0099-3.

Marechal, J.C., Dewandel, B., Ahmed, S., Galeazzi, L., Zaidi, F.K., 2006. Combined estimation of specific yield and natural recharge in a semi-arid groundwater basin with irrigated agriculture. J. Hydrology 329 (1-2), 281-293.

Masson, S., Gauvain, M., Mesléard, F., Dutoit, T., 2015. Impacts of water stress removal and disturbance regimes on Mediterranean dry grasslands diversity and succession. Plant Ecol. 1-19.

Meixner, T., Manning, A.H., Stonestrom, D.A., Allen, D.M., Ajami, H., Blasch, K.W., Brookfield, A.E., Castro, C.L., Clark, J.F., Gochis, D.J., others, 2016. Implications of projected climate change for groundwater recharge in the western United States. J. Hydrol. 534, 124-138.

Merot, A., Bergez, J.E., Wallach, D., Duru, M., 2008. Adaptation of a functional model of grassland to simulate the behaviour of irrigated grasslands under a Mediterranean climate: the Crau case. Eur. J. Agron. 29 (4), 163-174.

Naranjo, G., Cruz-Fuentes, T., Cabrera, M.D., Custodio, E., 2015. Estimating natural recharge by means of chloride mass balance in a volcanic aquifer: northeastern gran canaria (canary islands, Spain). Water 7, 2555-2574. https://doi.org/10.3390/ 7062555.

Olioso, A., et al., 2013. Modelling of drainage and hay production over the Crau aquifer for analysing impact of global change on aquifer recharge. In: Romano, N., Durso, G., Severino, G., Chirico, G.B., Palladino, M. (Eds.), Four Decades of Progress in Monitoring and Modeling of Processes in the Soil-plant-atmosphere System: Applications and Challenges. Procedia Environmental Sciences, pp. 691-700.

Scanlon, B.R., Healy, R.W., Cook, P.G., 2002. Choosing appropriate techniques for quantifying groundwater recharge. Hydrogeol. J. 10, 18-39.

Scanlon, B.R., Jolly, I., Sophocleous, M., Zhang, L., 2007. Global impacts of conversions from natural to agricultural ecosystems on water resources: quantity versus quality. Water Resour. Res. 43.

Séraphin, P., 2016. Contribution du traçage isotopique ( $\delta 180$ et $\delta \mathrm{D})$ à la compréhension et à la modélisation hydrogéologique de la nappe de la Crau. $\mathrm{PhD}$ thesis Aix Marseille Université, 257.

Séraphin, P., Vallet-Coulomb, C., Goncalves, J., 2016. Partitioning groundwater recharge between rainfall infiltration and irrigation retune flow using stable isotopes: the Crau Aquifer. J. Hydrology 542, 241-253.

Stigter, T.Y., van Ooijen, S.P.J., Post, V.E.A., Appelo, C.A.J., Dill, A., 1998. A hydrogeolog ical and hydrochemical explanation of the groundwater composition under irrigated land in a Mediterranean environment, Algarve, Portugal. J. Hydrology 208 (3-4), 262-279.

Tang, Q., Hu, H., Oki, T., 2007. Groundwater recharge and discharge in a hyperarid alluvial plain (Akesu, Taklimakan Desert, China). Hydrol. Process. 21 (10), 1345-1353.

Wahi, A.K., Hogan, J.F., Ekwurzel, B., Baillie, M.N., Eastoe, C.J., 2008. Geochemical quantification of semiarid mountain recharge. Ground Water 46 (3), 414-425.

Winograd, I.J., Riggs, A.C., Coplen, T.B., 1998. The relative contributions of summer and cool-season precipitation to groundwater recharge, Spring Mountains, Nevada, USA Hydrogeology J. 6 (1), 77-93.

Yakirevich, A., Weisbrod, N., Kuznetsov, M., Villarreyes, C.R., Benavent, I., Chavez, A.M., Ferrando, D., 2013. Modeling the impact of solute recycling on groundwater salinization under irrigated lands: a study of the Alto Piura aquifer, Peru. J. Hydrol. 482, 25-39. 